\title{
Maximizing Land Equivalent Ratio and Economic Return by Intercropping Maize with Peanut under Sandy Soil in Egypt
}

\author{
A. A. Metwally, S. A. Safina ${ }^{\#}$ and Y. A. A. Hefny* \\ Agronomy Department, Faculty of Agriculture, Cairo University and 'Crop \\ Intensification Research Department, Field Crops Research Institute, Agricultural \\ Research Center (ARC), Giza, Egypt.
}

\begin{abstract}
7 WO FIELD experiments were conducted at the experimental and research station at Ismailia of the Agriculture Research Center (ARC) Egypt, during 2013 and 2014 summer seasons in sandy soil; to determine the effect of intercropping maize with peanut under maize treatments; harvesting maize for fodder, maize for grains with defoliation at 85 days from sowing maize or without defoliation and plant densities: 2, 3 and 4 plants/hill at distance of $70 \mathrm{~cm}$ apart on each of productivity, land equivalent ratio (LER), net return and monetary advantage index (MAI). A split plots design with three replications was used. The main plots were assigned to three maize treatments and maize plant densities were distributed in sub plots. Sprinkler irrigation system was used, ground nut was sowing on both sides of beds $120 \mathrm{~cm}$ but corn was growing in the middle. Maize variety SC168 and groundnut C.V. Giza.6 were sown inboth seasons. The results showed that harvested maize plants for fodder produced the highest increment in pod yield/ha by (54.59 and $27.80 \%$ ), during the first and second seasons, respectively, as compared with intercropped groundnut plants with harvested maize for grains without defoliation. Sowing maize by low plant density (24000 plants/ha) resulted in higher values of pod yield/ha (2.147 and 2.077 ton) during the first and second seasons, respectively. Groundnut plants which grown with harvested maize for fodder and low densities of adjacent two maize plants/hill (24000 plants/ha) recorded the highest values of pod yield/ha (2.482 and 2.304 ton) in both seasons. The relationship between maize plant densities and pod yield of ground nut was negative and followed the linear equation. Linear regression equation for maize plant densities suggested that increase in one unit (12000 plants) of maize plant densities lead to decreased pod yield/ha by 0.410 and 0.368 ton/ha during the first and second seasons, respectively. Maximum values of green fodder (17.46 and 17.93 ton) were obtained with $100 \%$ maize (48000 plants/ha), while, the minimum values (13.33 and 16.11 ton) were obtained in 50\% maize density (24000 plants/ ha) in first and second seasons, respectively. Maize harvested for grains without defoliation produced the highest grain yield/plant (154.2 and $162.6 \mathrm{~g}$ ) and grain yield/ha (3.667 and 4.080 ton) during the first and second seasons, respectively. Maximum values of maize traits were obtained with intercropped 50\% maize (24000 plants/ha).Grain yield/ha (4.46 and 4.78 ton) reached maximum values at full stand and harvested maize plants for grains without defoliation during both seasons. Maximum LER (1.64 and 1.69) were obtained when the maize harvested for fodder and peanut plants were grown under low density (24000 plants/ ha) during the two seasons, respectively. Maximum net return/ha (1696.2 and 836.9 US\$) were recorded when the maize harvested for grains with defoliation and peanut plants were grown under $50 \%$ of full stand of maize plants (24000 plants/ha). The highest MAI value $(+830.5$ and +889.3$)$ was observed when the harvested maize plants for fodder and peanut plants were grown under $50 \%$ of full stand of maize plants ( 24000 plants $/$ ha).
\end{abstract}

Keywords: Peanut, Maize, Intercropping, LER, MAI.

\#Corresponding author email: drsayedsafina@agr.cu.edu.eg

DOI : 10.21608/agro.2018.2168.1087

C2018 National Information and Documentation Center (NIDOC) 


\section{Introduction}

In sandy soil of Egypt, where peanut is considered the main summer crop, intercropping is popular now among the small holders in Egypt. A reason for this popularity is built on profit and resource maximization and efficient water utilization. In many parts of the world, intercropping is a way of the most common in Agro-ecosystem is used, that has lots of advantages in comparison to sole crop (Banik et al., 2006). Small farmers in many countries are seriously constrained by limited land resources, intercropping have shown that possible ways for increasing the productivity on this area and increasing their return.

Groundnut (Arachis hypogaea L.) is one of the most important summer oil in the world. Groundnut seeds contain high oil (45\%), 26$28 \%$ protein, $20 \%$ carbohydrates and $5 \%$ fiber (Fageria et al., 1997). The cultivated area of groundnut in Egypt during 2013-2014 season was about 56,866 hectare (FAO, 2014). Recently groundnut in Egypt has been given great attention due to its suitability for growing in the newly reclaimed sandy areas.

Maize (Zea mays L.) is the first summer cereal crop in Egypt 'considering acreage, and total production'. In cereal-legume intercropping systems the cereal benefits from the nitrogen fixed by the legume crops and from the decomposition of nutrient rich biomass from root; and nodules of the legume, therefore, the increased yield of maize may be attributed to nitrogen fixing ability of legumes (Chen et al., 2004 and Metwally et al., 2007), helping to increase soil organic matter (Gregrich et al., 2001 and Metwally et al., 2007).

Intercropping peanut with maize attracted the attention of some investigators as Liphadzi et al. (1997), Abd El-Motaleb \& Yousef (1998), Metwally et al. (2005) and Hefny et al. (2017).

Metwally et al. (2005) reported that low density of groundnuts per ridge had higher values of pod number and yield per plant than those of high plant density in solid and intercropping cultures. Studies on maize densities whether maize spacing or number of maize plant/hill which remain after thinning and the fertilization rate and the intercropping pattern seemed to be of prime importance in optimizing the association.

Several researchers on intercropping systems noted that yield of one or all of the crops in the intercrop were lower than that of the total of the pure stands. Land equivalent ratio (LER) was used as a criterion for measuring affiance of intercropping advantage by comparing the intercropped area with mono-cropping (Mead \& Willey, 1980). Abou-Keriasha et al. (2009) found that the highest land equivalent ratio (LER) recorded was 1.29 and the monetary L.E. was 1874.52. Abou-Keriasha et al. (2012) concluded that the total land equivalent ratio (LER) value (1.22) when intercropped maize with soybean or cowpea. Shams et al. (2012) results revealed that intercropping peanut grown $50 \%$ of full maize stand $\left(2.4\right.$ plants $\left./ \mathrm{m}^{2}\right)$ in $(1: 1)$ pattern under orientated at $70 \mathrm{~cm}$ apart leaving two plants/hill and adding $120 \mathrm{~kg} \mathrm{~N} /$ fad for the two components resulted in maximum net return of 1851.71 and 2214.95 L.E. with maximum LER of 1.44 and 1.41 in first and second season, respectively. Abou-Keriasha et al. (2013) showed that the highest values of LER (1.35) were observed when the winter crop was wheat. The highest values of the intensification index (2.64) were observed by the crop sequence faba bean + onion/maize + cowpea. The crop sequence berseem/maize + cowpea recorded the highest values of cereal unit, while the crop sequence wheat + fahlberseem/maize + cowpea had the highest values for total revenue and net return.

Abou-Keriasha et al. (2012) showed that the highest values of monetary advantage index (MAI) (1044.46 LE) were observed when intercropping with soybean at 4:4 pattern, while the lowest value was observed in maize+sorghum intercrop at 2:4 pattern.

Therefore, the objective of the present study is to determine the effect of intercropping maize with peanut under maize treatments; harvesting maize for fodder, or grains with defoliation at 85 days from sowing maize, as well as, maize without defoliation with plant densities: 2, 3 and 4 plants/hill at distance of $70 \mathrm{~cm}$ apart on each of productivity, land equivalent ratio (LER), net return and monetary advantage index (MAI).

\section{Materials and Methods}

\section{Experimental site}

Two field trials were carried out at the experimental and research station at Ismailia of the Agriculture Research Center (ARC) Egypt, during 2013 and 2014 in summer seasons. The soil was sandy textured $(26.32 \%$ coarse sand, 
$68.37 \%$ fine sand, $3.82 \%$ silt and $1.49 \%$ clay), with $\mathrm{pH} 7.76$ and $0.19 \%$ organic matter content, $0.34 \mathrm{EC}\left(\mathrm{dmS}^{-1}\right), 22.17 \mathrm{ppm}$ available $\mathrm{N}, 2.83$ ppm available $\mathrm{P}$ and $42.76 \mathrm{ppm}$ available $\mathrm{K}$. (Average of the two seasons).

Plant material, treatments and experimental design

Peanut cv. Giza 6 (Main crop) was seeded on $10^{\text {th }}$ and $15^{\text {th }}$ May in 2013 and 2014 seasons, respectively, whereas maize cv. single cross 168 was seeded on $25^{\text {th }}$ and $30^{\text {th }}$ May in 2013 and 2014 seasons, respectively. Maize grains and peanut seeds kindly provided from ARC, Egypt. Maize was sown of three maize plant population densities, i.e., two plants/hill (24,000 plants/ ha, $50 \%$ of the recommended solid planting), three plants/hill (36,000 plants/ha, 75\%) and four plants/hill (48,000 plants/ha, 100\%) on $70 \mathrm{~cm}$ between hill under intercropping maize planting. Maize treatments were (M1: maize harvested for fodder at 85 days from sowing, M2: maize for grains with defoliation of maize at 85 days from maize sowing, leaves were tacked as fodder to animals by small farmers and M3: maize for grains without defoliation). Peanut was planted on both sides of beds (120 $\mathrm{cm}$ ) by growing two plants per hill distanced at $20 \mathrm{~cm}$ apart under intercropping. Recommended solid plantings of groundnut plants were sown on one sides of ridges $(60 \mathrm{~cm})$ by growing two plants per hill distanced at $20 \mathrm{~cm}$ apart, as well as solid planting of maize were sown on ridges $(60 \mathrm{~cm})$ by growing one plant/hill distanced at $30 \mathrm{~cm}$ apart (48000 plants/ha).

A randomized complete block design (RCBD) in a spilt plot with three replications was used. The main plots were assigned to maize treatments, whereas plant densities were distributed in sub plots. The plot size was $19.2 \mathrm{~m}^{2}$. Each sub-plot consisted of four beds; each was $4 \mathrm{~m}$ in length and $1.2 \mathrm{~m}$ width for intercropping, as well as, 8 ridges $60 \mathrm{~cm}$ width for recommended solid groundnut and corn.

\section{Agricultural practices}

A sprinkler irrigations systems was used and carried out every week. Phosphate fertilizer was added during land preparation at the rate of 480 $\mathrm{kg} / \mathrm{ha}$ in the form of Calcium Super Phosphate $\left(15.5 \% \mathrm{P}_{2} \mathrm{O}_{5}\right)$, whereas, potassium sulphate $(48 \%$ $\mathrm{K}_{2} \mathrm{O}$ ) at a rate of $240 \mathrm{~kg} / \mathrm{ha}$ was added in two equal doses at sowing and after 30 days. Nitrogen fertilization was applied to maize plants by the rate of $480 \mathrm{~kg} / \mathrm{ha}$ ammonium sulfate $(20.6 \% \mathrm{~N})$ in three equal doses at 15, 30 and 45 days after sowing. All agronomic practices were carried out according to technical recommendations of groundnut at Ismailia Governorate.

\section{Data recorded \\ Peanut}

At harvest (after 120 days from planting) the middle two beds or 4 ridges of each plot $\left(12 \mathrm{~m}^{2}\right)$ were harvested to determine yield per hectare, weight of pods/plot $(\mathrm{kg})$ was converted to hectare $\left(10000 \mathrm{~m}^{2}\right)$ to determine pod yield by ton/ha.

\section{Maize}

Maize harvested for fodder at 85 days from sowing; The middle two beds of each plot (12 $\mathrm{m}^{2}$ ) were harvested to determine each of yield per plot, green fodder $/$ plot $(\mathrm{kg})$ and converted to ton per hectare $\left(10000 \mathrm{~m}^{2}\right)$ to determine green fodder by ton/ha. Also, maize plants of the middle two beds were defoliation leaves at the age of 85 days from sowing as green fodder .

At harvest (120 days from planting) a sample of adjacent ten plants were taken, from the pure stand and intercropped plots of maize to determine grain yield/plant $(\mathrm{g})$ and shilling \%. The middle two beds of each plot $\left(12 \mathrm{~m}^{2}\right)$ were harvested for determine weight of grains/plot (kg) and hectare (ton) were determined.

\section{Competitive relationships and yield advantage} Land equivalent ratio (LER)

LER determined as the sum of the two fractions of the yield of the intercrops relative to their sole crop yields according to the following formula (Willey, 1979):

$$
\mathrm{LER}=[(\mathrm{Yab} / \mathrm{Yaa})+(\mathrm{Yba} / \mathrm{Ybb})]
$$

where: Yaa and Ybb means: Pure stand yield of crop (a) and (b), respectively. Yab and Yba means: Intercrop yield of crop (a) and (b), respectively.

\section{Farmer's benefit \\ Net return $\mathrm{ha}^{-1}$}

Total return of intercropping cultures = Price of peanut yield + price of maize yield (US dollars \$). Prices of peanut (pods) and maize were used according to Bulletin of Statistical Cost Production and Net Return (2015). The prices of peanut (pods) was 614.0 US \$ per ton, meanwhile maize grain was 234.9 US $\$$ per ton and green fodder 46.1 US \$ 
Net return per ha of intercropping $=$ Total return - (fixed costs of peanut + variable costs of maize).

\section{Monetary advantage index (MAI)}

It suggests that the economic assessment should be in terms of the value of land saved; this could probably be most assessed on the basis of the rentable value of this land. MAI was calculated according to the formula, suggested by Willey (1979).

$\mathrm{MAI}=\{$ Value of combined intercrops $\mathrm{X}$ (LER-

$$
\text { 1) }\} / \text { LER }
$$

\section{Statistical analysis}

The data recorded were statistically analyzed by using analysis of variance technique of the RCBD for various agronomic characteristics (Steel et al., 1997). The least significant difference (LSD) test at probability level of 5\% was used to determine the statistical differences between means when the $\mathrm{F}$ value was significant. The data were statistically analyzed by using the computer statistical software package MSTAT-C (Freed et al., 1989) and for drawing the diagrams, Excel software was used.

\section{Results and Discussion}

\section{Peanut productivity}

\section{Effect of maize treatments}

Harvested maize plants for fodder gave higher and significant increments than other treatments in pod yield/ha, these increments were 54.59 and $27.80 \%$, more than intercropping maize for grain during the first and second seasons, respectively. In addition, defoliation of maize plants at 85 days age caused significant increase in pod yield/ha by (27.17 and 26.34\%), during the first two season, respectively (Table 1 and Fig.1). Also, there was a great reduction in pods yield/ha by intercropping maize with peanut as compared with solid peanut culture, this reductions were increased by the period of intercropped both crops $(27.6 \%$ $51.7 \%)$.

Accumulation of dry matter by a crop is directly dependent upon the amount of radiation intercepted by the crop canopy. Removal maize plants for fodder by about 30 days before harvesting maize plants for grains with or without defoliation maize plants before harvesting. These treatments caused favorable environmental conditions for growing peanut especially light intensity during pod formation and maturation.

Reduced light intensity decreased photosynthesis and carbohydrate concentrations in leaves and pods (Metwally et al., 2005; Sherif et al., 2005; Abdel-Galil et al., 2014 and Kubota et al., 2015). These results are in agreement with those obtained by Hefny et al. (2017) who reported that the early time of harvesting and removal maize plants (about 50 days) before harvesting peanut plants led to subject peanut plants to suitable environmental conditions which were available during pod formation and maturation.

Regression analysis reveal the relation between the two variables, i. e., maize treatments (x) and yield of pods/ha (y), there was a linear relation, and highly significant $(\mathrm{P} \leq 0.01)$ correlation coefficient ( $\mathrm{r}=1$ and 0.78$)$ during the first and second seasons, respectively (Fig.2). Besides, R2 (coefficient of determination), revealed that it was possible to account up to $1 \%$ and 0.88 of the variability in yield of pods/ha (y), to maize treatments during the first and second seasons, respectively. The relationship between maize treatments and yield of pods/ha was negative and followed the linear equation: of $Y=2.473-0.371 x$ and $\mathrm{Y}=2.221-0.236 \mathrm{x}$, representing a negative value of (b), during the first and second seasons, respectively, which means yield decrease against harvested maize plants to grain (Fig. 2).

\section{Effect of maize plant densities}

Pod yield per ha was affected significantly by growing maize by different plant densities during the first and second seasons (Table 1 and Fig.3). Results indicated that higher value was obtained when peanut was grown under low density $50 \%$ (24000 plants/ha). If produced pod yield/ha (2.147 and 2.077 ton) during the first and second seasons, respectively; this may be attributed to more light penetration than those grown under heavy maize densities (36000 and 48000). These results are in accordance with those obtained by (Abd-El Motaleb \& Yousef, 1998; Metwally et al., 2005; Mas-uda et al., 2016 and Hefny et al., 2017). A gradual reduction in groundnut traits as plant densities increased up to 48000 plants/ ha was recorded. These reductions were occurred by 38.19 and $35.44 \%$, during the first and second seasons, respectively (Table 1).

The present results are in agreement with those obtained by Jana \& Saren (1998), Ghosh (2002) and Hussein et al. (2002). Hefny et al. (2017) reported that minimum groundnut yield was obtained when intercropped with full density of maize (48000 plants/ha). 
TABLE 1. Effect of maize treatments, population densities and their interaction on pod yield/ha of peanut at 2013 and 2014 seasons.

\begin{tabular}{lccc}
\hline & & \multicolumn{2}{c}{ Pod yield/ha, ton } \\
Maize & $\begin{array}{c}\text { Maize plant densities } \\
\text { (plants/ha) }\end{array}$ & First season & Second season \\
& & $\mathbf{2 0 1 3}$ & 2.304 \\
\cline { 2 - 3 } & 24000 & 2.482 & 1.970 \\
Harvested maize & 36000 & 2.101 & 1.536 \\
plants for fodder (M1) & 48000 & 1.726 & $\mathbf{1 . 9 3 6}$ \\
& Mean & $\mathbf{2 . 1 0 3}$ & 2.244 \\
Maize for grains under & 24000 & 2.113 & 1.857 \\
Defoliation (M2) & 36000 & 1.750 & 1.446 \\
& 48000 & 1.327 & $\mathbf{1 . 8 4 9}$ \\
Maize for grains & Mean & $\mathbf{1 . 7 3}$ & 1.685 \\
without defoliation (M3) & 24000 & 1.845 & 1.667 \\
& 36000 & 1.309 & 1.042 \\
Mean for maize & 48000 & 0.929 & $\mathbf{1 . 4 6 4}$ \\
plant densities & Mean & $\mathbf{1 . 3 6 1}$ & 2.077 \\
\hline LSD 0.05: Maize treatments (A) & & 2.147 & 1.831 \\
Maize plant densities (B) & & 1.720 & 1.341 \\
A X B & & 1.327 & 0.823 \\
Solid peanut (Mo) & 36000 & 0.117 & 0.965 \\
\hline
\end{tabular}

\# First season $2013 \quad$ a Second season 2014

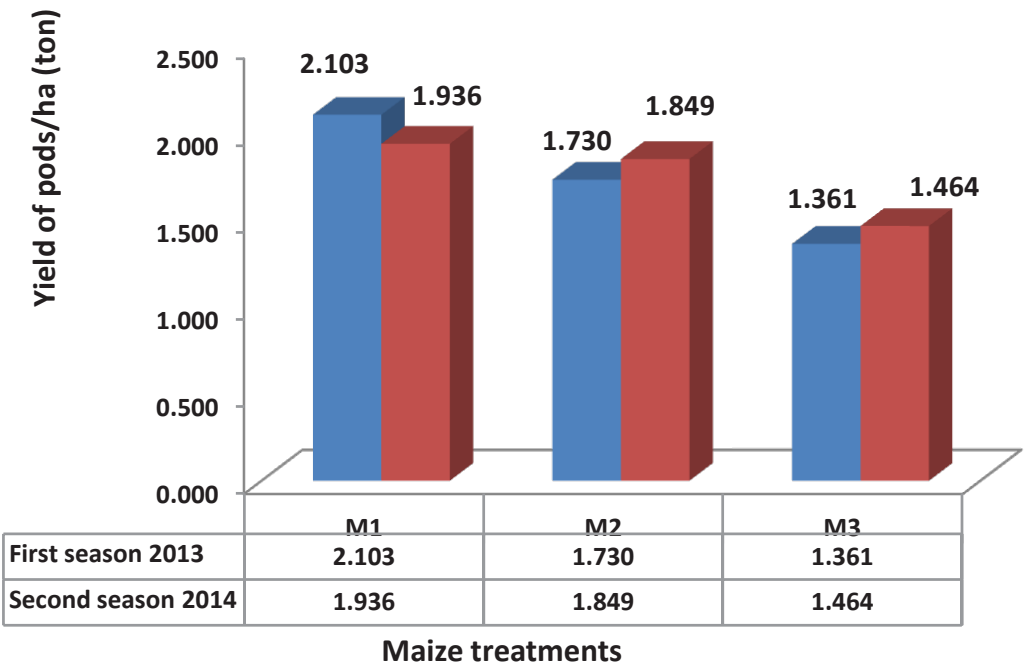

M1= Harvested maize plants for fodder, M2= Maize for grains under defoliation, M3= Maize for grains without defoliation.

Fig.1. Productivity (pod yield/ha, ton) under the three treatment of maize in 2013 and 2014 seasons. 

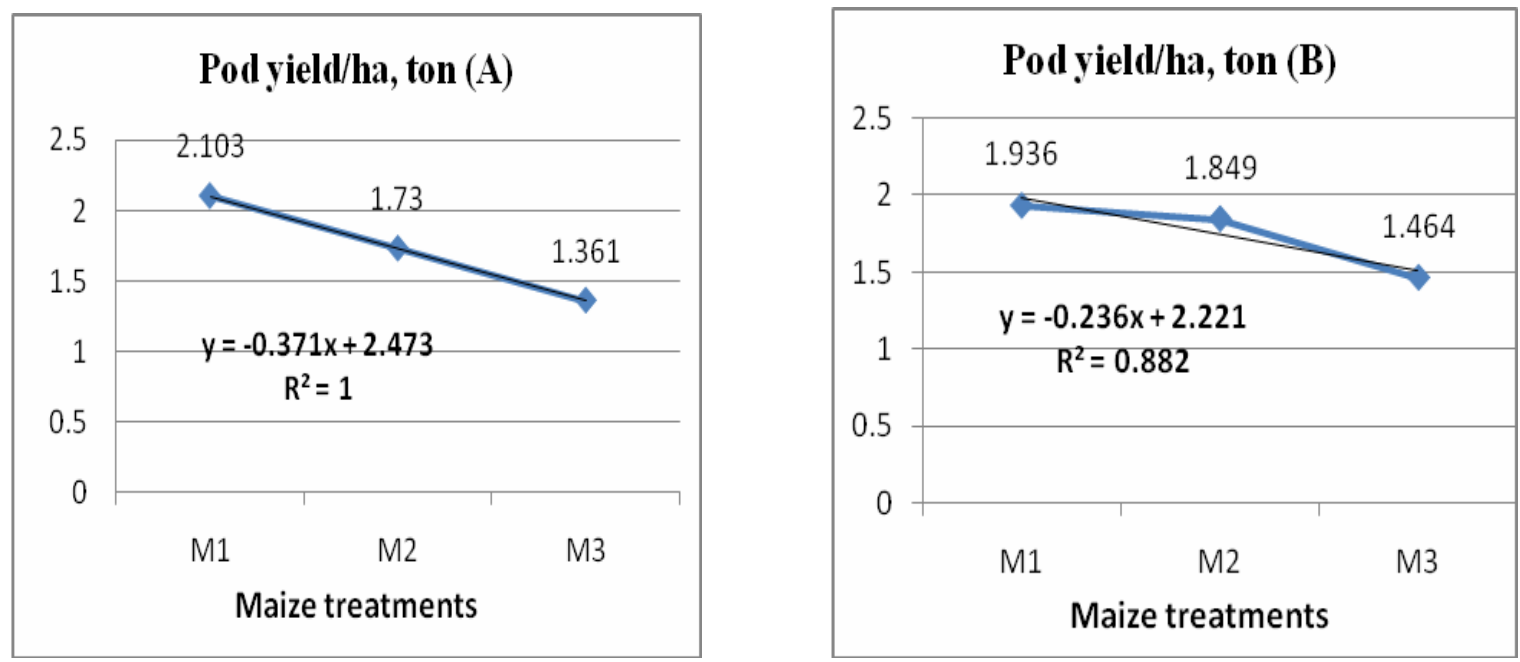

M1= Harvested maize plants for fodder, M2= Maize for grains under defoliation, M3= Maize for grains without defoliation.

Fig.2. Relationships between maize treatments and pod yield (ton/ha) in 2013 (A) and 2014 (B) seasons.

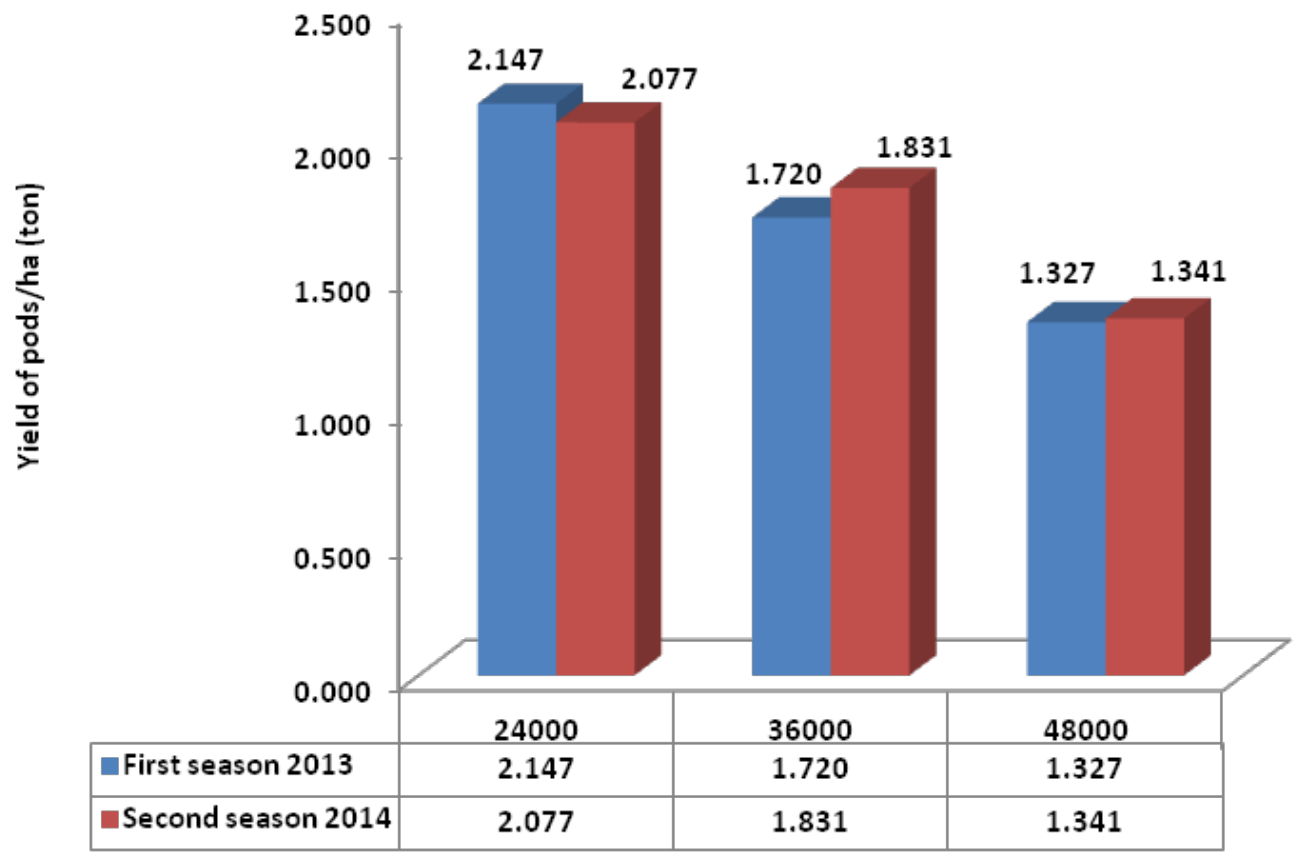

Fig.3. Productivity (pod yield/ha, ton) under the three planting densities of maize in 2013 and 2014 seasons.

Results in Fig.4 indicate that regression analysis reveal the relations between the two variables, i. e., maize plant densities $(x)$ and pod $\mathrm{yield} / \mathrm{ha}(\mathrm{y})$ indicated a linear relation as well as a highly significant $(\mathrm{P} \leq 0.01)$ correlation coefficient $(\mathrm{r}=1)$ occurred during the first and second seasons. Besides, R2 (coefficient of determination), revealed that it was possible to account up to $99 \%$ and 0.96 of the variability in yield of pods/ha (y), to maize plant densities during the first and second seasons, respectively. The relationship between maize plant densities and pod yield/ha was negatively and followed the linear equation: of $\mathrm{Y}=2.551-0.41 \mathrm{x}$ and $\mathrm{Y}=2.485$ $0.368 \mathrm{x}$, representing a negative value of (b), during the first and second seasons, respectively, 
which mean yield decrease against increase maize plant densities (Fig. 2). Linear regression equation for maize plant densities suggested that increase

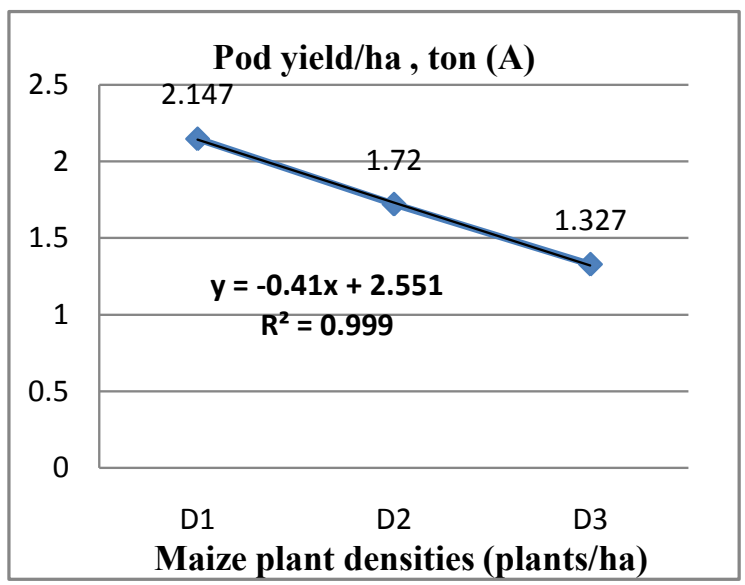

in one unit (12000 plants) lead to reduction pod yield/ha by 0.41 and 0.368 ton/ha during the first and second seasons, respectively.

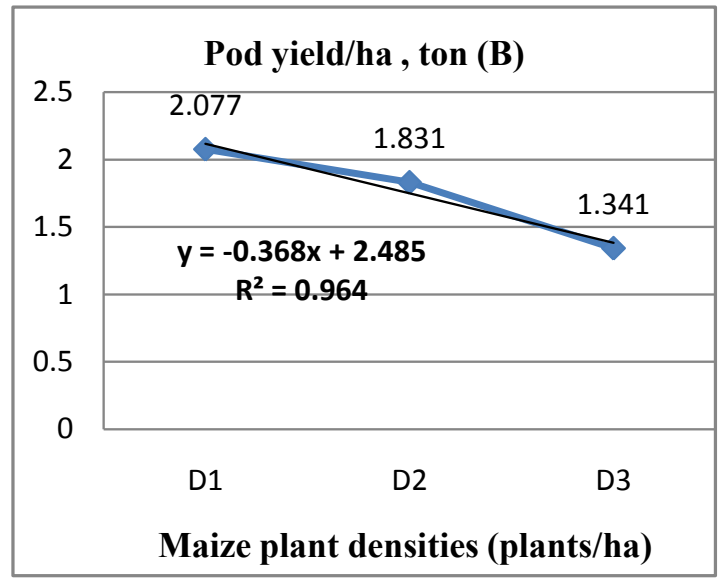

Fig.4. Relationships between maize plant densities and pod yield (ton/ha) in 2013 (A) and 2014 (B) seasons.

\section{Interaction effects}

The interaction between maize treatments and maize plant population densities on pod yield/ ha was significant (Table1). Groundnut plants which grown with harvested maize for fodder and low densities of adjacent two maize plants/ hill (24000 plants/ha) recorded the highest values of pod yield/ha (2.482 and 2.304 ton) during both seasons (Table1); whereas, groundnut plants which were grown with harvested maize plants for grains under intercropping with heavy densities of maize plants (four plants/hill; 48000 plants/ ha) had the lowest values of pod yield/ha (0.929 and 1.042 ton) during the first and second seasons, respectively. This result was in the same line with that reported by Abdel-Galil et al. (2014), Safina et al. (2014) and Hefny et al. (2017).

\section{Productivity of maize}

\section{Effect of maize treatments}

Results in Table 2 indicate that maize yields and its components were significantly influenced by maize treatments under intercropping in both seasons. The results indicate that values of the yield and its component were always higher when maize was harvested for grains and without defoliation than those recorded of defoliation maize in both seasons. The maize harvested for grains without defoliation produced the highest grain yield/plant (154.2 and $162.6 \mathrm{~g})$, shilling \% (68.78 and 69.42) and grain yield/ha (4.04 and 4.15 ton) during the first and second seasons, respectively, whereas the grain with defoliation of maize plants produced the lowest values of traits.

Defoliation of maize plants decreased photosynthesis and carbohydrate concentrations in grains (Abdel-Galil et al., 2014; Metwally et al., 2015 and Hefny et al., 2017).

Effect of population of intercropping maize plants

Results in Table 2 indicate that the values of grain yield/plant and shilling \% decreased with increasing maize density, except green fodder/ ha increased with increasing maize density in both seasons. Consequently maximum values of these traits were obtained with 50\% maize (24000 plants/ha), while, the minimum values were obtained in 100\% maize density (48000 plants/ ha). Maximum yield of green fodder (17.46 and 17.93 ton) were obtained with $100 \%$ of maize population densities (48000 plants/ha), while, the minimum values (13.33 and 16.11 ton) were obtained with $50 \%$ maize density (24000 plants/ ha) in first and second seasons, respectively. The results hold true in both seasons. The increments in components of maize yield may be due to the reduction of maize plant density and less competition between plants for light, water, nutrient minerals and place. The similar results were obtained by several investigators. El-Bana \& Gomaa (2000); Ibrahim \& Abd El-Maksoud (2001); Abdel-Galil et al. (2014) and Hefny et al. (2017) demonstrated that maize yield component, increased with decreasing maize density of intercropping systems. 
TABLE 2. Effect of maize treatments, plant population densities and their interaction on grain yield/plant, shilling $\%$, grain yield/ha and green fodder yield/ha of intercropped maize with peanut at 2013 and 2014 seasons.

\begin{tabular}{|c|c|c|c|c|c|}
\hline $\begin{array}{l}\text { Maize } \\
\text { Treatments }\end{array}$ & $\begin{array}{l}\text { Maize plant } \\
\text { Densities } \\
\text { (plants/ha) }\end{array}$ & $\begin{array}{l}\text { Grain yield/ } \\
\text { plant (g) }\end{array}$ & $\underset{\%}{\text { Shilling }}$ & $\begin{array}{l}\text { Grain yield/ } \\
\text { ha, ton }\end{array}$ & $\begin{array}{l}\text { Green fodder } \\
\text { yield/ha, ton }\end{array}$ \\
\hline \multicolumn{6}{|c|}{ First season 2013} \\
\hline \multirow{4}{*}{$\begin{array}{l}\text { Harvested maize } \\
\text { plants for fodder }\end{array}$} & 24000 & - & - & - & 13.33 \\
\hline & 36000 & - & - & - & 15.07 \\
\hline & 48000 & - & - & - & 17.46 \\
\hline & Mean & - & - & - & 15.29 \\
\hline \multirow{4}{*}{$\begin{array}{l}\text { Maize for grains under } \\
\text { defoliation }\end{array}$} & 24000 & 140.6 & 77.85 & 3.31 & - \\
\hline & 36000 & 120.9 & 59.40 & 3.97 & - \\
\hline & 48000 & 87.5 & 56.37 & 4.30 & - \\
\hline & Mean & 116.3 & 64.54 & 3.86 & - \\
\hline \multirow{4}{*}{$\begin{array}{l}\text { Maizefor grains } \\
\text { without defoliation }\end{array}$} & 24000 & 173.0 & 81.13 & 3.37 & - \\
\hline & 36000 & 158.6 & 65.90 & 4.29 & - \\
\hline & 48000 & 131.0 & 59.32 & 4.46 & - \\
\hline & Mean & 154.2 & 68.78 & 4.04 & - \\
\hline \multirow{3}{*}{$\begin{array}{l}\text { Mean for maize } \\
\text { plant densities }\end{array}$} & 24000 & 156.8 & 79.49 & 3.34 & - \\
\hline & 36000 & 139.7 & 62.65 & 4.13 & - \\
\hline & 48000 & 109.2 & 57.84 & 4.38 & - \\
\hline LSD $_{005}:$ Maize treatments (A) & & 7.5 & 1.86 & 0.20 & - \\
\hline Maize plant densities (B) & & 2.33 & 2.75 & 0.09 & 0.48 \\
\hline $\mathrm{AXB}$ & & 3.30 & NS & 0.12 & - \\
\hline Solid (Recommended) & & 93.11 & 63.8 & 4.95 & 16.84 \\
\hline \multicolumn{6}{|c|}{ Second season 2014} \\
\hline \multirow{3}{*}{$\begin{array}{l}\text { Harvested maize } \\
\text { plants for fodder }\end{array}$} & 24000 & - & - & - & 16.11 \\
\hline & 36000 & - & - & - & 16.14 \\
\hline & 48000 & - & - & - & 17.93 \\
\hline \multirow{6}{*}{$\begin{array}{l}\text { Maize for grains under } \\
\text { defoliation }\end{array}$} & Mean & - & - & - & 16.72 \\
\hline & 24000 & 152.3 & 79.29 & 2.76 & - \\
\hline & 36000 & 131.3 & 61.41 & 3.27 & - \\
\hline & 48000 & 106.7 & 57.18 & 3.96 & - \\
\hline & Mean & 130.1 & 65.96 & 3.33 & - \\
\hline & 24000 & 180.0 & 81.98 & 3.48 & - \\
\hline \multirow{2}{*}{$\begin{array}{l}\text { Maize for grains } \\
\text { without defoliation }\end{array}$} & 36000 & 165.5 & 65.77 & 4.18 & - \\
\hline & 48000 & 142.3 & 60.51 & 4.78 & - \\
\hline \multirow{4}{*}{ Mean for Plant densities } & Mean & 162.6 & 69.42 & 4.15 & - \\
\hline & 24000 & 166.2 & 80.64 & 3.12 & - \\
\hline & 36000 & 148.4 & 63.59 & 3.73 & - \\
\hline & 48000 & 124.5 & 58.85 & 4.37 & - \\
\hline $\mathrm{LSD}_{0.05}:$ Maize treatments (A) & & 5.09 & 3.96 & 0.17 & - \\
\hline Maize plant densities (B) & & 5.33 & 2.47 & 0.23 & 0.61 \\
\hline $\mathrm{AXB}$ & & 7.54 & NS & 0.32 & - \\
\hline Solid (Recommended) & & 97.84 & 65.73 & 5.13 & 18.55 \\
\hline
\end{tabular}

$\mathrm{NS}=$ not significant.

Maximum maize yield was obtained (4.38 and $4.37 \mathrm{ton} / \mathrm{ha}$ ) by increasing plant density to 48000 $\mathrm{pl} / \mathrm{ha}$, whilst the lowest yield (3.34 and 3.12 ton/ha) was obtained from $50 \%$ maize density ( $24000 \mathrm{pl} / \mathrm{ha}$ ) during the first and second seasons, respectively, due to more light interception which was lesser than in $100 \%$ and stimulate plant development may explain the greater yield in 50\% compared with the other densities. These data was in agreement by Metwally et al. (2009).

\section{Interaction effects}

Grain yield per plant and ha were affected significantly by the interaction between maize treatments and maize plant densities, whereas, shilling \% was not affected in both seasons (Table 2 ). It is clear that the highest value of grain yield/ 
plant (173.0 and $180.0 \mathrm{~g}$ ) was recorded when maize plant density decreased to $50 \%$ of its full stand while the converse was true with grain yield/ ha. These results coincide with those explained by Eliseu \& Freire (1992); Metwally et al. (2005 and 2015) and Hefnyet al. (2017).

\section{Land equivalent ratio (LER)}

The values of LERs were estimated by using data of recommended solid plantings of both crops. Relative yields (Ry) of peanut and maize were affected significantly by maize treatments and maize plant densities (Table 3, Fig.5 and 6). Relative yields of peanut and maize were higher by intercropping maize with peanut which harvested for fodder than others. These results may be due to removal maize plants as fodder (one month) before harvesting maize plants for grains create favorable environmental conditions especially light intensity which was more available to peanut plants during pod formation and seed maturation.

The results reveal that the Ry peanut values of the main crop (peanut) were affected by maize treatments and maize plant densities. The highest mean value $(0.714$ and 0.692$)$ was observed in harvested maize plants for fodder during the first and second seasons, respectively, but lesser than in harvested maize plants for grains which indicate that there was an advantage for peanut when intercropping with maize harvested plants for fodder by increase light intensity which was more available to peanut plants. Moreover, the Ry peanut and maize values were affected by maize plant densities. When increasing plant densities increased Ry maize and decreased Ry peanut in both seasons. This results due to increased yield or decreased yield under intercropping. The 24000 plants/ha $(50 \%)$ had higher mean over all values of Ry peanut (0.728 and 0.742) and 48000 plants/ ha $(100 \%)$ had lowest values $(0.450$ and 0.479$)$ during the first and second seasons, respectively.

Land equivalent ratio values in Table 3, Fig.5 and 6 indicated clearly that all values obtained under the treatment imposed exceeded the unit indicating yield advantage as compared when each component was grown alone. These results were true in both seasons. Results of the interaction indicate that LER obtained from harvested maize plants for fodder were generally superior to defoliation or without for grains either. Moreover,
LER values (1.62 and 1.59) of harvested maize plants for fodder were always higher than in another maize treatment under same respective maize plant densities, respectively during the first and second seasons. The trend of LERs decreased by increasing intercropped maize plants. This may be due to more shade effects on yield of peanut by increasing corn densities, and consequently more reduction of peanut yield.

Maximum LER (1.64 and 1.69) were obtained when maize harvested for fodder and peanut plants were grown under the $50 \%$ of maize plants (24000 plants/ha) for both seasons. This indicates that 64 and $69 \%$ more area would be required by sole cropping system to equal the yield of the intercropping pattern. While, minimum LER (1.22 and 1.28) were obtained when the maize was grown for grains without defoliation and heavy plant density at both seasons.

Yield advantage in the intercrop as compared with sole cropping were supported by Calavan \& Weil (1988) who found that peanut-maize intercrop resulted in land equivalent rate ranging from 1.28 to 1.49 and Eliseu \& Freire (1992) who also found that peanut-maize intercrop gave yield advantage estimated to $1.20-1.99$, particularly in peanut-maize $(3: 1)$.

Also, these results are in the same trend with those obtained by Metwally (1999), Metwally et al. (2005, 2009, 2015 and 2017a) when soybean was grown under intercropping with maize.

\section{Net return $h a^{-1}$}

Results on net return presented in Table 3, Fig.7 and 8 also indicated that the treatment effect had apparent decrease on net return with an increases in corn plant densities from 24000 to 48000 plants/ha under maize for grains with and without defoliations on both seasons. Maximum net return (1696.2 and 836.9 US \$) were recorded when the maize harvested for grains with defoliation and intercropped with peanut and grown under $50 \%$ of full stand of maize plants (24000 plants/ha), but the minimum net return (671.8 and 352.3 US \$) were recorded when maize harvested for grains without defoliation and peanut plants were grown under $100 \%$ of full stand of maize plants $(48000$ plants/ha) for both seasons. The study suggested that intercropping peanut with maize plants is more profitable to farmers than solid planting of peanut. 
TABLE 3. Land equivalent ratios (LER), net return and MAI as affected by maize treatments, maize plant population densities and their interactionin 2013 and 2014 seasons.

\begin{tabular}{|c|c|c|c|c|c|c|}
\hline \multirow{2}{*}{$\begin{array}{l}\text { Maize } \\
\text { Treatments }\end{array}$} & \multirow{2}{*}{$\begin{array}{c}\text { Maize plant } \\
\text { densities } \\
\text { (plants/ha) }\end{array}$} & \multicolumn{2}{|c|}{$\begin{array}{l}\text { Relative yield (ton/ } \\
\text { ha) }\end{array}$} & \multirow[t]{2}{*}{ LER } & \multirow{2}{*}{$\begin{array}{c}\text { NET } \\
\text { Return(US\$/ha) }\end{array}$} & \multirow[t]{2}{*}{ MAI } \\
\hline & & Maize & Peanut & & & \\
\hline \multicolumn{7}{|c|}{2013 season } \\
\hline \multirow{5}{*}{$\begin{array}{l}\text { Harvested maize } \\
\text { plants for fodder }\end{array}$} & 24000 & 0.793 & 0.842 & 1.64 & 715.9 & 830.5 \\
\hline & 36000 & 0.897 & 0.713 & 1.61 & 721.1 & 752.0 \\
\hline & 48000 & 1.039 & 0.586 & 1.63 & 769.3 & 717.1 \\
\hline & Mean & 0.910 & 0.714 & 1.62 & 735.4 & 766.5 \\
\hline & 24000 & 0.669 & 0.717 & 1.39 & 1696.2 & 500.4 \\
\hline \multirow{3}{*}{$\begin{array}{l}\text { Maize for grains under } \\
\text { defoliation }\end{array}$} & 36000 & 0.802 & 0.594 & 1.40 & 1632.7 & 527.4 \\
\hline & 48000 & 0.869 & 0.45 & 1.32 & 1531.4 & 471.5 \\
\hline & Mean & 0.780 & 0.587 & 1.37 & 1620.1 & 504.5 \\
\hline \multirow{4}{*}{$\begin{array}{l}\text { Maize for grains } \\
\text { without defoliation }\end{array}$} & 24000 & 0.681 & 0.626 & 1.31 & 1193.1 & 367.4 \\
\hline & 36000 & 0.867 & 0.444 & 1.31 & 960.6 & 387.9 \\
\hline & 48000 & 0.901 & 0.315 & 1.22 & 671.8 & 286.2 \\
\hline & Mean & 0.816 & 0.462 & 1.28 & 941.8 & 349.3 \\
\hline \multirow{3}{*}{$\begin{array}{l}\text { Mean for maize } \\
\text { plant densities }\end{array}$} & 24000 & 0.714 & 0.728 & 1.45 & 1201.7 & 566.1 \\
\hline & 36000 & 0.855 & 0.584 & 1.44 & 1104.8 & 555.8 \\
\hline & 48000 & 0.936 & 0.450 & 1.39 & 990.8 & 491.6 \\
\hline \multicolumn{2}{|c|}{ LSD 0.05: Maize treatments (A) } & 0.013 & 0.041 & 0.01 & 319.1 & 179.6 \\
\hline \multicolumn{2}{|c|}{ Maize plant densities (B) } & 0.015 & 0.046 & 0.06 & 94.1 & 83.0 \\
\hline \multicolumn{2}{|l|}{ A X B } & 0.025 & 0.079 & 0.10 & 163.0 & 143.8 \\
\hline \multicolumn{7}{|c|}{2014 season } \\
\hline \multirow{3}{*}{$\begin{array}{l}\text { Harvested maize } \\
\text { plants for fodder }\end{array}$} & 24000 & 0.869 & 0.823 & 1.69 & 741.8 & 889.3 \\
\hline & 36000 & 0.870 & 0.704 & 1.57 & 736.6 & 718.7 \\
\hline & 48000 & 0.967 & 0.549 & 1.52 & 797.6 & 608.1 \\
\hline \multirow{5}{*}{$\begin{array}{l}\text { Maize for grains under } \\
\text { defoliation }\end{array}$} & Mean & 0.902 & 0.692 & 1.59 & 758.7 & 738.7 \\
\hline & 24000 & 0.538 & 0.802 & 1.34 & 836.9 & 369.7 \\
\hline & 36000 & 0.637 & 0.664 & 1.30 & 656.7 & 344.5 \\
\hline & 48000 & 0.772 & 0.517 & 1.29 & 479.4 & 375.3 \\
\hline & Mean & 0.649 & 0.661 & 1.31 & 657.7 & 367.0 \\
\hline \multirow{4}{*}{$\begin{array}{l}\text { Maize for grains } \\
\text { without defoliation }\end{array}$} & 24000 & 0.678 & 0.602 & 1.28 & 553.6 & 325.8 \\
\hline & 36000 & 0.815 & 0.596 & 1.41 & 589.0 & 479.3 \\
\hline & 48000 & 0.932 & 0.372 & 1.30 & 352.3 & 381.0 \\
\hline & Mean & 0.809 & 0.523 & 1.33 & 498.3 & 396.7 \\
\hline \multirow{3}{*}{$\begin{array}{l}\text { Mean for maize Plant } \\
\text { densities }\end{array}$} & 24000 & 0.695 & 0.742 & 1.44 & 710.8 & 528.3 \\
\hline & 36000 & 0.774 & 0.655 & 1.43 & 660.8 & 514.2 \\
\hline & 48000 & 0.890 & 0.479 & 1.37 & 543.1 & 454.8 \\
\hline \multicolumn{2}{|c|}{ LSD 0.05: Maize treatments (A) } & 0.013 & 0.041 & 0.06 & 148.4 & 270.7 \\
\hline \multicolumn{2}{|c|}{ Maize plant densities (B) } & 0.033 & 0.046 & 0.03 & 63.4 & 72.4 \\
\hline \multicolumn{2}{|c|}{$\mathrm{AX} \mathrm{B}$} & 0.056 & 0.079 & 0.06 & 109.9 & 125.5 \\
\hline
\end{tabular}

Prices of main products are that of 2015: US \$ 614.0 for ton of peanut pods, US \$234.9 for ton of maize and 46.1US $\$$ for ton of green fodder. Net return of solid peanut=938.1 and 847.2 US \$/ha in 2013 and 2014 seasons, respectively. 
A

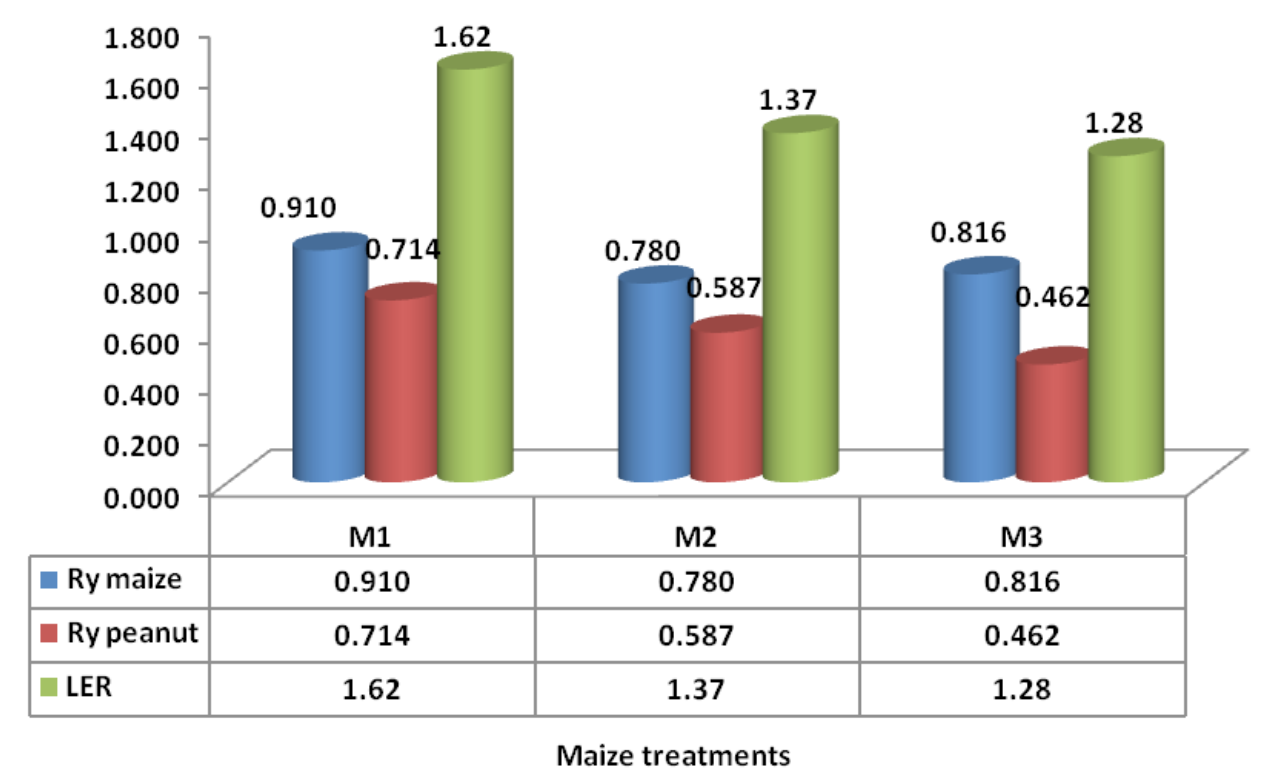

B

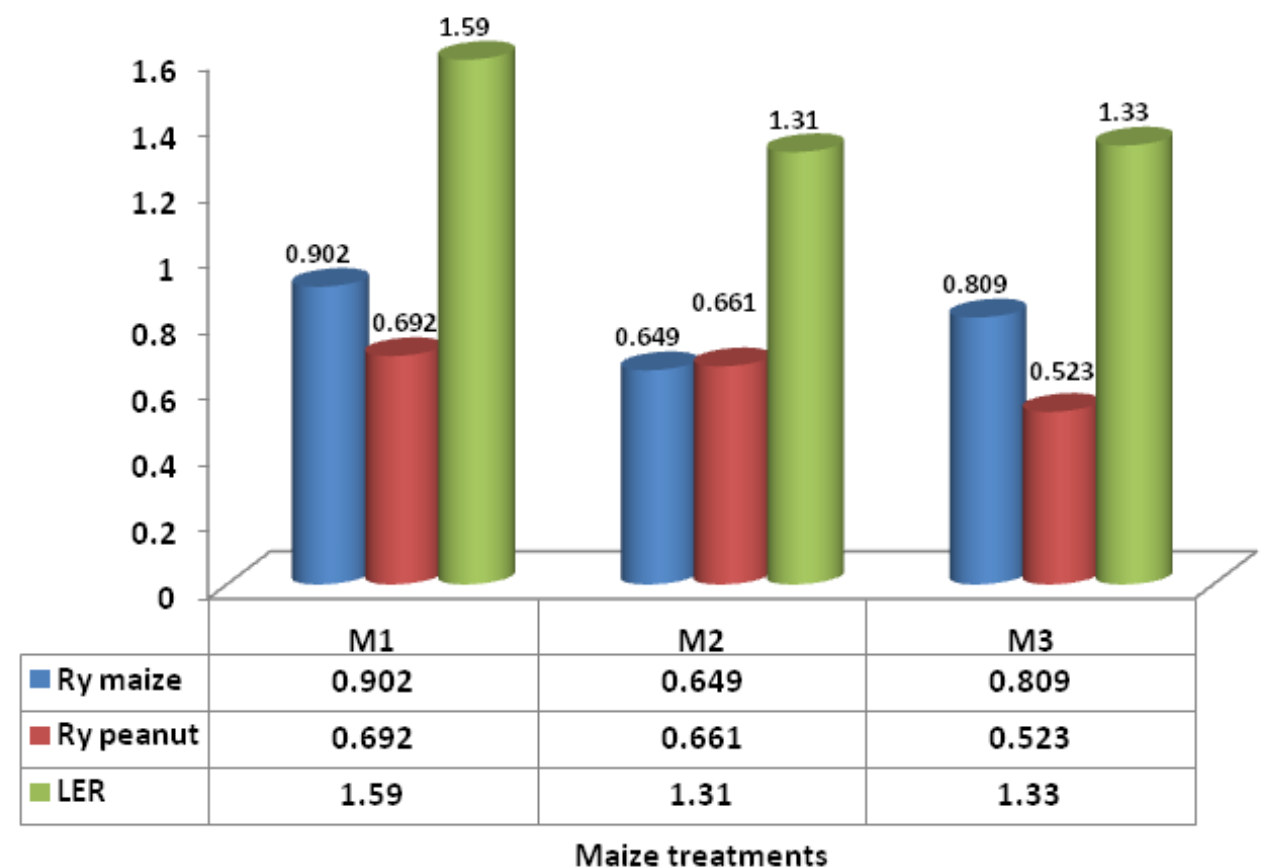

M1= Harvested maize plants for fodder, M2= Maize for grains under defoliation, M3= Maize for grains without defoliation.

Fig.5. Effect of maize treatments on relative yields of peanut and maize and land equivalent ratio (LER) in maize + groundnut intercropping systems over time in 2013 (A) and 2014 (B). 
A

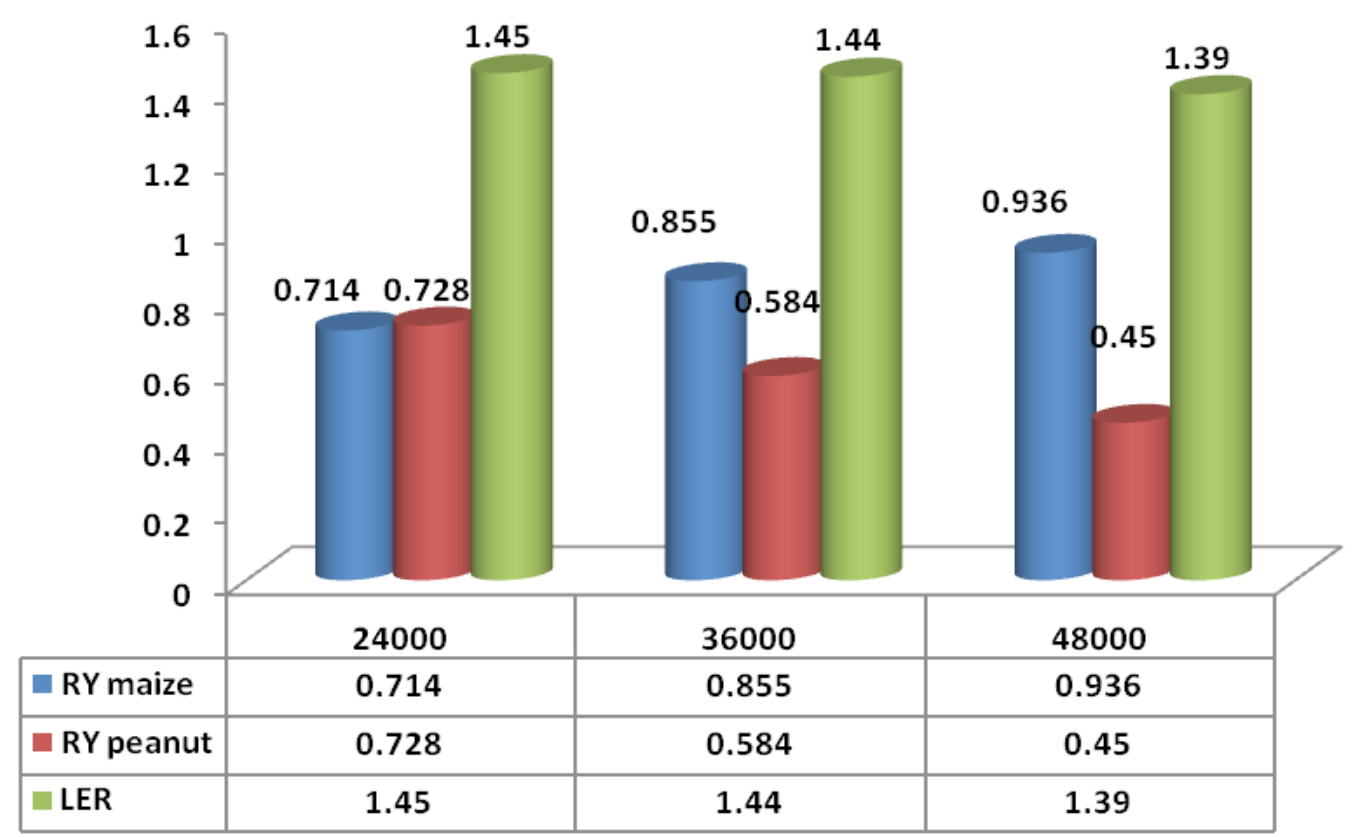

Maize plant densities (plants/ha)

B

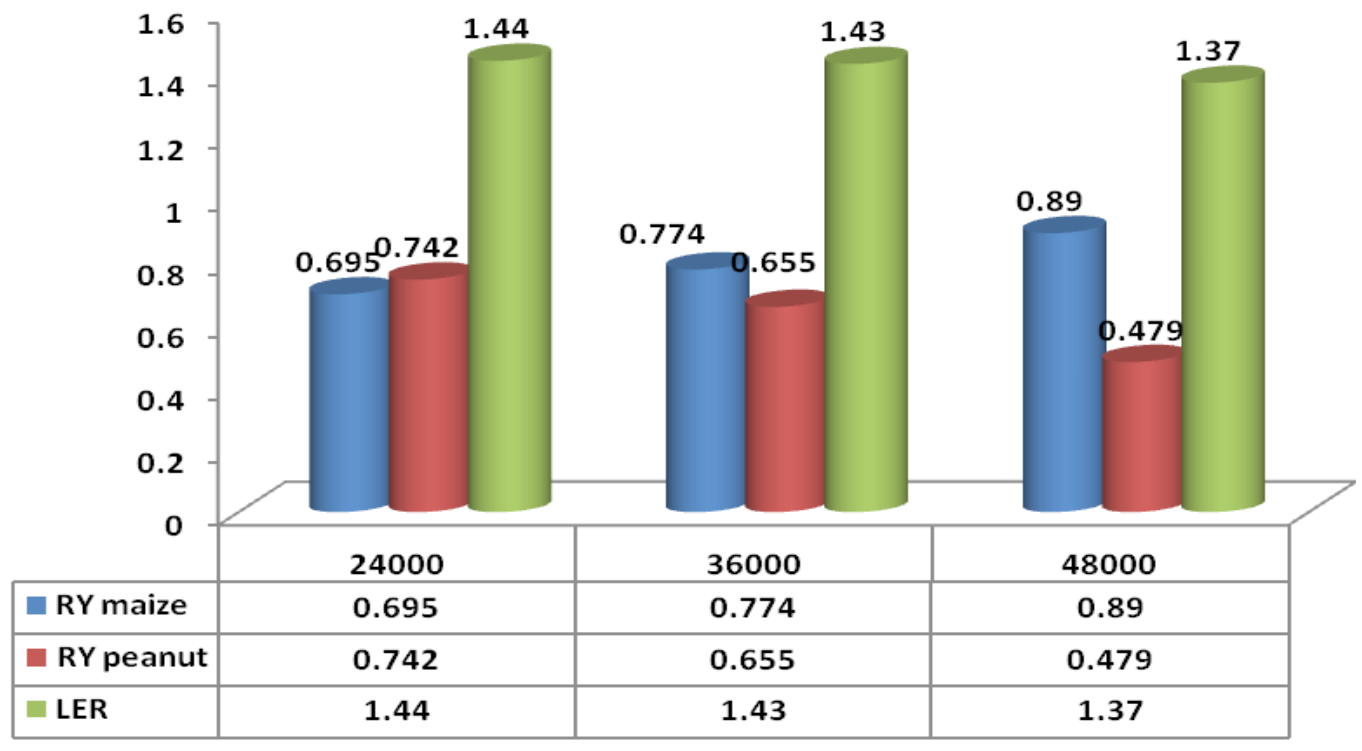

Maize plant densities (plants/ha)

M1= Harvested maize plants for fodder, M2= Maize for grains under defoliation, M3= Maize for grains without defoliation .

Fig.6. Effect of maize treatments on relative yields of peanut and maize and land equivalent ratio (LER) in maize + groundnut intercropping systems over time in 2013 (A) and 2014 (B). 


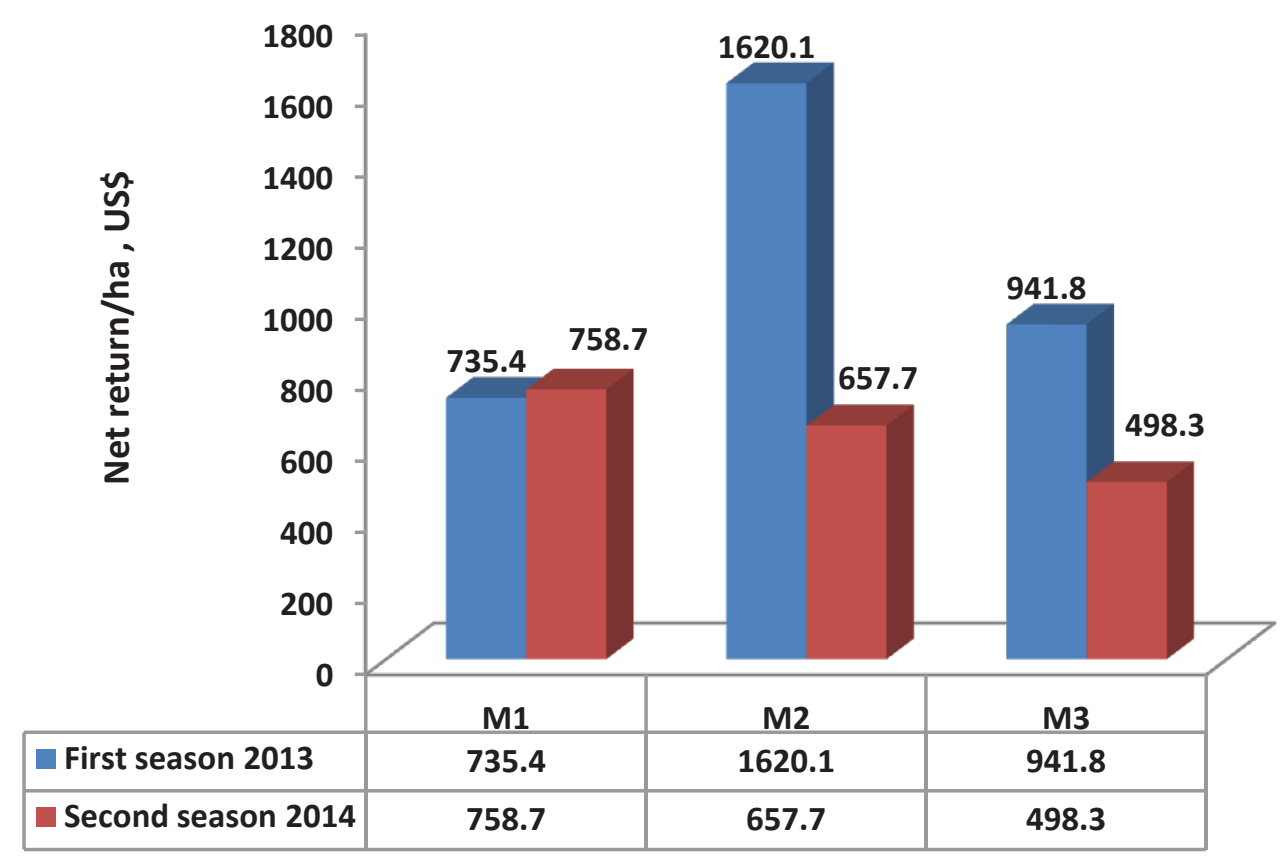

\section{Maize treatments}

M1= Harvested maize plants for fodder, M2= Maize for grains under defoliation, M3= Maize for grains without defoliation .

Fig.7. Effect of maize treatments on net return per ha in maize + groundnut intercropping systems over time in 2013 and 2014 seasons.

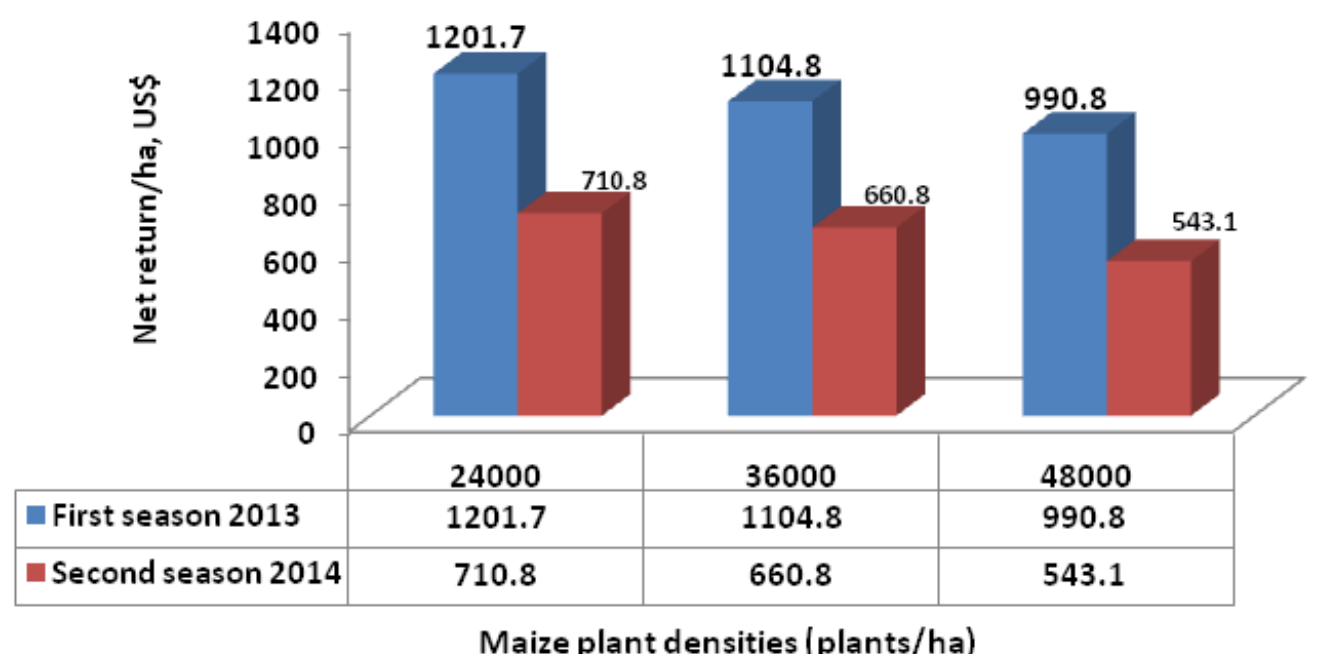

Fig.8. Effect of maize plant densities on net return per ha in maize+groundnut intercropping systems over time in 2013 and 2014 seasons. 
Metwally et al. (2009 and 2012), Metwally et al. (2017b) mentioned that mixed intercropping pattern between corn:soybean and corn:cotton gave higher financial values when using high population densities of both crops and distributing the maize plants at a wide distance between hills (four maize plants per hill at $70 \mathrm{~cm}$ apart).

\section{Monetary advantage index (MAI)}

The MAI values were positive in all cases in both seasons. These positive MAI values were observed in the other treatments which had LER values greater than one (Table 3).

The highest MAI value $(+830.5$ and +889.3$)$ was observed when the harvested maize plants for fodder and peanut plants were grown under $50 \%$ of full stand of maize plants $(24000$ plants/ ha), while the lowest value $(+286.2$ and +325.8$)$ was observed when the maize for grains without defoliation and peanut plants were grown under $100 \%$ of full stand of maize plants (48000 plants/ ha) during the first and $50 \%$ of full stand of maize plants (24000 plants/ha) in the second seasons, respectively.

Similarly, Dhima et al. (2007) and AbouKeriasha et al. (2009) found that economic benefit expressed with higher MAI values in intercropping.

\section{Conclusion}

The study suggested that intercropping peanut with maize plants is more profitable to farmers than solid planting of peanut provided farmers use suitable treatments. Maximum LER and MAI were obtained when maize was grown with peanut and harvested for fodder, as well as, for grains under $50 \%$ of corn plants. Maximum net return were recorded when the maize harvested for grains under defoliation and peanut plants were grown under $50 \%$ of full stand of maize plants.

\section{References}

Abdel-galil, A.M., Abdel-Wahab, T.I. and AbdelWahab, Sh.I. (2014) Maize productivity under intercropping with four soybean varieties and maize planting geometry. Middle East J. Agric. Rese. 3(2), 346-352.

Abd El-Motaleb, H.M. and Yousef, M.S.H. (1998) Intercropping maize with two varieties of peanut under two levels of nitrogen fertilizer. Proc. $8^{\text {th }}$ Conf. Agron., Suez Canal Univ., Ismaillia, Egypt, 28-29 Nov. pp.544-552.
Abou-Keriasha, M.A., Abd El-Hady, M.A. and Nawar, F.R. (2009) Response of some cowpea varieties to intercropping with maize under upper Egypt condition. Egypt. J. Appl. Sci. 24(2B), 495-514.

Abou-Keriasha, M.A., Eisa, N.M.A. and Lamlo, M.M. (2013) Benefits of legume crops in rotation and intercropping for increased production and land use. Egypt. J. Agron. 35(2), 183-197.

Abou-Keriasha, M.A., Mohamed, W.Kh., Eisa, N.M. and Kamel, A.S. (2012) Intensive crop rotations to improve agricultural production in middle Egypt. Egypt. J. Agric. Res. 90(4), 427-443.

Banik, P., Midya, A., Sarkar, B.K. and Ghose, S.S. (2006) Wheat and chickpea intercropping systems in an additive series experiment: Advantages and weed smothering. European J. Agron. 24, 325-332. http://dx.doi.org/10.1016/j.eja.2005.10.010.

Bulletin of Statistical Cost Production and Net Return. (2015)Winter field crops and vegetables and fruit, Agriculture Statistics and Economic Sector, Ministry of Egyptian Agriculture and Land Reclamation, Part (1), February 2015.

Calavan, K.M. and Weil, R.R. (1988) Peanut-corn intercrop performance as affected by within-row corn spacing at a constant row spacing. Agron. J. 80, 635-642.

Chen, C.M., Cott, W., Neill, K., Wichman, D. and Knox, M. (2004) Row configuration and nitrogen application for barley-pea intercropping in Montana. Agron. J. 96, 1730-1738.

Dhima, K.V., Lithourgidis, A.S., Vasilakoglou, I.B. and Ordas, C.A.D (2007) Competition indices of common vetch and cereal intercrops in two seeding ratio. Field Crops Res. 100, 249-256.

El-Bana, A.Y. and Gomaa, M.A. (2000) Effect of N and $\mathrm{K}$ fertilization on maize grown in different populations under newly reclaimed sandy soil. Zagazig J. Agric. Res. 27(5), 1179-1196.

Eliseu, J.M. and Freire, M.J. (1992) Effect of plant density and sowing pattern on the yield of a groundnut/maize intercrop. Proc. $5^{\text {th }}$ Regional Groundnut Workshop for Southern Africa, 9-12 March, Lilongwe, Malawi. pp.121-123.

Fageria, N.K., Baligar, V.C. and Jones, C. (1997)"Growth and Mineral Nutrition of Field Crop". $2^{\text {nd }}$ (ed.), Marcel Dakker, Inc, New York 1001 K. pp. 494.

FAO (2014) Food and Agriculture Organization of the 
United Nations. Giews country briefs. http://faostat. fao.org/site/567/default.aspx\#ancor.

Freed, R.S.P., Einensmith, S., Gutez, S., Reicosky, D., Smail, V.W. and Wolberg, P. (1989) User's guide to MSTAT-C analysis of agronomic research experiments. Michigan Univ. East Lansing, USA.

Ghosh, P.K. (2002) Agronomic and economic evaluation of groundnut (Arachis hypogaea L.). Cereal fodder intercropping during the post rainy season. Indian J. Agron. 47(4), 509-513.

Gregrich, E.C.; Drury, C.F. and Baldock, J.A. (2001) Changes in soil carbon under long-term maize in monoculture and legume- based rotation. Can. J. Soil Sci. 81, 21-31.

Hefny, Y.A.A., Safina, S.A. and Sheha, A.M. (2017) Evaluation of intercropping groundnut (Arachis hypogaea L.) with maize under different plant densities in sandy soils. Egypt. J. Agron. 39(1), 9-18.

Hussein, S.M.A., Shams, A.S. and El Melegy, M.A. (2002) Effect of some intercropping patterns and foliar application with nutrients mixure on yield of maize and peanut. Annals of Agric. Sci. Moshtohor, 40(3), 1427-1447.

Ibrahim, A.A. and Abd El-Maksoud, M.F. (2001) Leaf defoliation and hill spacing effects on maize productivity. Zagazig J. Agric. Res. 28(2), 261-274.

Jana, P.K. and Saren, B.K. (1998) Dry matter accumulation, yield attributes and yield of summer maize (Zea mays L.) and groundnut (Arachis hypogaea L.) intercropping systems as influenced by irrigation. Indian J. Agron. 43(1), 18-22.

Kubota, A., Safina, S.A., Shebl, S.M., Mohamed, A.H., Ishikawa, N., Katsuyoshi, S., Abdel-Gawad, K. and Sachio, M. (2015) Evaluation of intercropping system of maize and leguminous crops in the Nile Delta of Egypt. Trop. Agr. Develop. 59(1), 14-19.

Liphadzi, M.S., Thomas, R.M. and Hammes, P.S. (1997) Competition between intercropped maize (Zea mays L.) and groundnut (Arachis hypogaea L.). App. Plant Sci. 11(2), 31-34.

Mas-uda, M., Kabab, J.S., Oforic, K. and Salifud, G. (2016) Relative panting dates effect on the agronomic performance of maize (Zea mays L.) and groundnut (Arachis hypogea L.) in an intercrop system. American Scie. Rese. J. Engineering, Techn. Scie. (ASRJETS), 16(1), 262-276.

Mead, R. and Willey, R.W. (1980) The concept of a "land equivalent ratio" and advantages in yields from intercropping. Exp. Agric. 16, 217-28.

Metwally, A.A. (1999) Intensive cropping systems in the battle against food crises. Proc. $1^{\text {st }}$ Congress on Recent Technologies in Agriculture, Cairo Univ. Fac. Agric. pp. 333-341.

Metwally, A.A., Mohamed, G.O., Shereif, M.N. and Awad, M.M. (2005) Yield and land equivalent ratio of intercropped maize and groundnut. The $11^{\text {th }}$ Conf. Egyptian Soc. Crop Sci., Assiut, Egypt, pp. 163-173.

Metwally, A.A., Shafik, M.M., Fayez, M. and Safina, S.A. (2007) Effect of nitrogen fertilization and diazotroph inoculation on yield of solid and intercropped maize with soybean. J. Agric. Sci. Mansoura Univ. 32(6), 4207-4215.

Metwally, A.A., Mahmoud, G.O., Sherief, M.N. and Abo Hegazy, D.R. (2009) Yield and land equivalent of intercropped corn and soybean under three intercropping patterns. The $4^{\text {th }}$ Conf., Recent Technologies in Agric., 3-5 Nov. Cairo Univ., 2, pp. 284-290.

Metwally, A.A., Shafik, M.M., El-Habbak, K.E. and Abdel-Wahab, Sh.I. (2012) Yield and soybean characters under some intercropping patterns with corn. Soybean Research, 10, 24-42.

Metwally, A. A., Safina, S. A. and Noaman, A.H. (2015) Yield and land equivalent ratio of intercropping maize with egyptian cotton. J. Agri-Food Appl. Sci. 3(4), 85-93.

Metwally, A.A., Safina, S.A., El-Killany, R. and Saleh, N.A. (2017a) Productivity, land equivalent ratios and water use efficiency of intercropping corn with soybean in Egypt. RJPBCS, 8(4), 328-344.

Metwally, A.A.,Safina, S.A., El-Killany, R. and Saleh, N.A. (2017b) Growing corn and soybean in solid and intercropping systems under different levels of irrigation. Water.Bio. Sci. Res. J. 14(3), 532-541.

Safina, S.A., Noaman, A.H. and Metwally, A.A. (2014) Productivity and fiber quality of two Egyptian cotton cultivars under solid and intercropping cultures with maize. Int. J. Agri. Crop Sci. 7(11), 778-785.

Shams, A.S., El-Debaby, A.S., Roshdy, A. and Kamel, A.S. (2012) Effect of maize plants distribution and nitrogen fertilization levels in peanut-maize intercrop. Egypt. J. Agron. 34(1), 39-52.

Sherif, S.A., Zohry, A.A. and Ibrahimi, S. (2005) Effect of planting dates and densities of maize 
intercropped with groundnut on growth, yield and yield components of both crops. Arab Univ. J. Agric. Sci. Ain Shams Univ., Cairo, 13(3), 771-791.

Steel, R.G.D., Torri, J.H. and Dickey, D.A. (1997)

"Principles and Procedures of Statistics: A
Biometrical Approach", $3^{\text {rd }}$ ed., McGraw-Hill, New York. 666p.

Willey, R.W. (1979) Intercropping: Its importance and research needs. I. Competition and yield advantages. Field Crop Abst. 32, 1-10.

\title{
تعظيم معدل كفاءة استخدام الارض والعائد الاقتصادي من خلال تحميل الذرة الشامية مع الفول السوداني تحت الارض الرملية في مصر الارض الأل
}

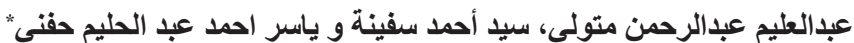

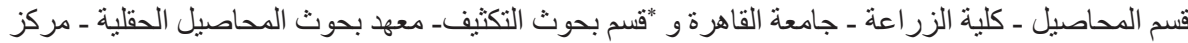

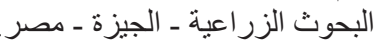

\begin{abstract}
أجريت تجربتان بمحطة التجارب الزر اعية بالإسماعيلية لمركز البحوث الزر اعية، بمحافظة الإسماعيلية، مصر

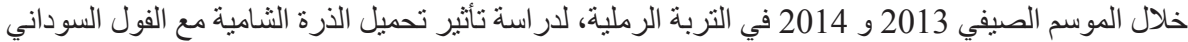

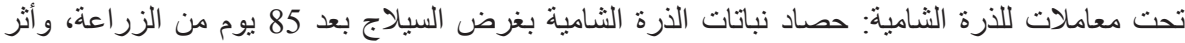

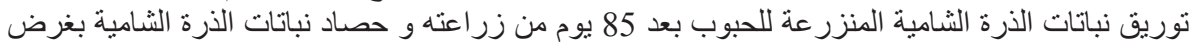

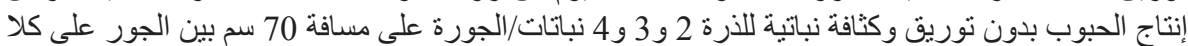

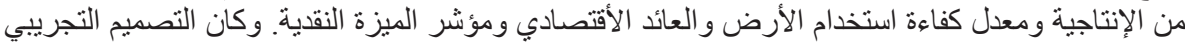

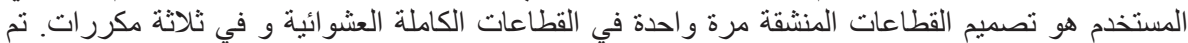

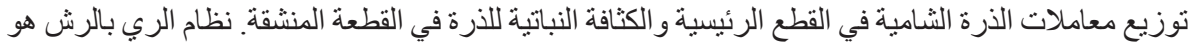

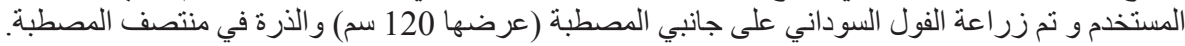

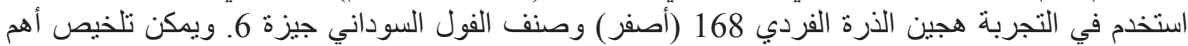

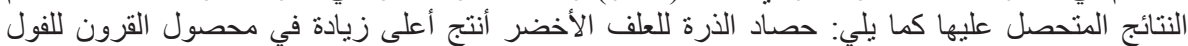

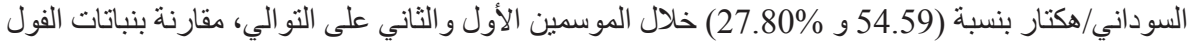

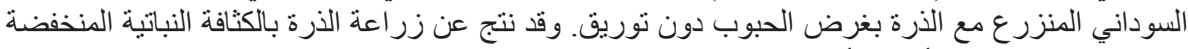

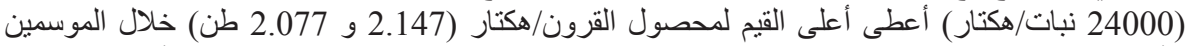

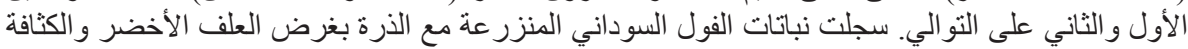

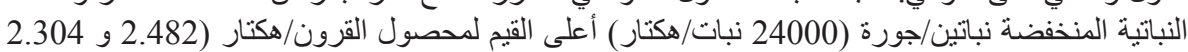

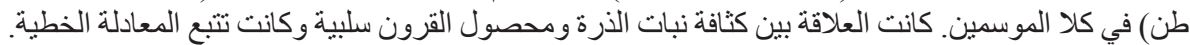

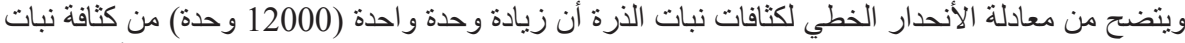

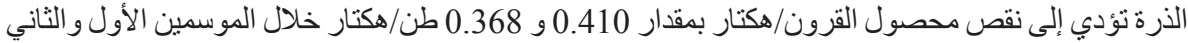

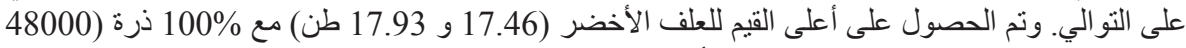

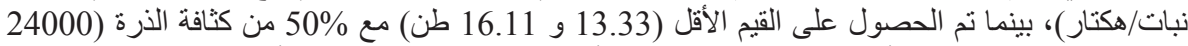

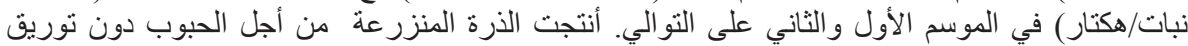

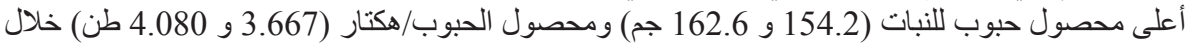

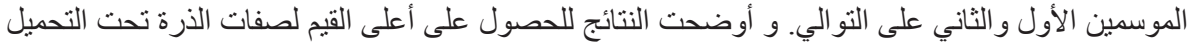

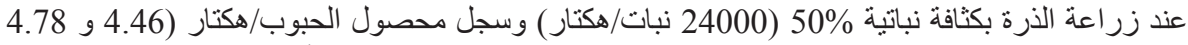

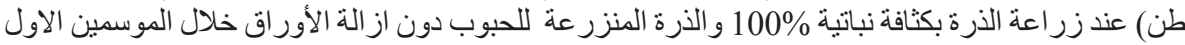

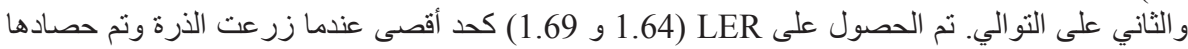

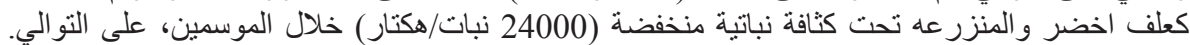

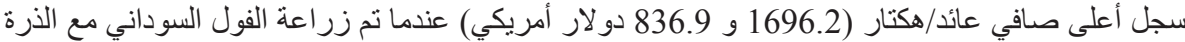

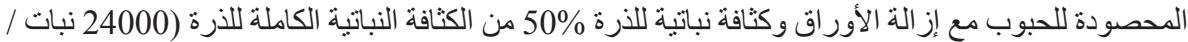

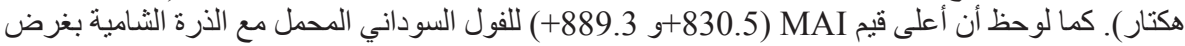
العلف الأخضر وبكثافة نباتية 50\% للأرة (24000 نبات/هكتار ).
\end{abstract}

